\title{
A comparative laboratory trial on the effect of Sargassum wightii incorporated formulated feed on growth performance and immunity development of Asian sea bass Lates calcarifer (Bloch 1790): Can it be an alternative to commercial feed?
}

\author{
H. Kodithuwakku ${ }^{1,2}$, M.G.I.S. Parakrama ${ }^{1 *}$, P.P.M. Heenatigala ${ }^{1}$, V. Pahalawattaarachchi ${ }^{1}$ \\ ${ }^{1}$ National Aquatic Resources Research and Development Agency, Crow Island, Colombo 15, Sri \\ Lanka \\ ${ }^{2}$ Department of Civil and Environmental Engineering, Faculty of Engineering, University of \\ Ruhuna, Sri Lanka
}

*Corresponding author (paraindrani@yahoo.com)

http://orcid.org/0000-0001-8668-982X

\begin{abstract}
Asian sea bass (Lates calcarifer) is a high valued seafood throughout the world. Bacterial infections can cause huge losses in Asian sea bass culture and among them Aeromonas hydrophila is ubiquitous. Inclusion of bioactive compounds present in seaweeds into fish diets can enhance the fish growth and immunity combating the bacterial diseases. This study was conducted to determine whether feeding with Sargassum wightii incorporated feed could enhance immunity of the fish to bacterial infections. A feed trial was conducted using four treatments comprising a commercial feed, two formulated feeds incorporated with $20 \mathrm{~g} / \mathrm{kg}$ and $40 \mathrm{~g} / \mathrm{kg}$ of $S$. wightii in each feed and a formulated feed without seaweed as the control diet. Three replicate tanks stocked with 15 advanced fingerlings were used for the each treatment and reared 40 days under the optimum conditions. Growth parameters were tested and effect of different feeds on growth performance was evaluated. Fish survival rate and cost of formulated feed were calculated. At the end of feed trial, nine fishes from each treatment were artificially challenged with $1.50 \mathrm{ppm}$ dose of A. hydrophila and observed for 7 days. There was a significant difference in weight gain in commercial feed compared to other three treatments $(\mathrm{P}<0.05)$, while there was no significant difference in FCR and SGR among all experimental diets $(\mathrm{P}>0.05)$. The challenge with $A$. hydrophila showed $11.1 \%$ disease prevalence in $L$. calcarifer fed with $20 \mathrm{~g} / \mathrm{kg}$ of seaweed incorporated feed. Highest disease prevalence of $100 \%$ was recorded in fish that had been fed with the seaweed free formulation. The highest level of immunity enhancement was reported using the feed that contained $20 \mathrm{~g} / \mathrm{kg}$ seaweed. Production cost of formulated feed was lower than the commercial feed.
\end{abstract}

Keywords: Sea bass, immunity, Aeromonas hydrophila, seaweed

\section{INTRODUCTION}

The Asian seabass, Lates calcarifer, is an important coastal, euryhaline carnivorous fish in the IndoPacific region and is a commercially important aquaculture species in Australia and South-East Asia (Anil et al. 2010). The attributes of being adaptable to a wide range of water salinity and turbidity probably make sea bass a suitable species for culture under captive conditions (Boonyaratpalin and Williams 2002). It is farmed in both brackish water and freshwater ponds, as well as in cages of coastal waters in many regions in the world. This fish fetches a high market price due to its delicately-flavored white meat. It has fast growth rate, can be fed with artificial feed or trash fish, and can be bred in captivity, thus making it a candidate species suitable for aquaculture. Presently sea bass culture has been identified as a promising investment opportunity in the marine aquaculture sector in Sri Lanka due to the high export demand.

Among these fish culture systems, bacterial diseases are common and many clinical signs of different bacterial diseases of cultured fish are similar. Among all the disease causing bacteria in Asian sea bass, Aeromonas hydrophila are ubiquitous which can be found in variety of aquatic environments worldwide. When infected with $A$. hydrophila, many fish species develop ulcers, fin rot, tail rot, and hemorrhagic septicemia (Abou El- 
Atta and El-Tantawy 2008) and gives great loses to fish culturists.

Sea bass culture practice needs comparatively high protein feed. The availability of cost effective, proper fish feed and prevention of disease make a bottle neck issue in fish culture system. Therefore, to overcome this problem, development of high protein and disease resistant feed type is a major requirement, and it is believed that it will help for the propagation of sea bass culture industry in Sri Lanka.

Seaweeds are marine macro algae which form an important component of the marine living resources of the world. They also produce a wide variety of chemically active metabolites to protect themselves against the other pathogenic organisms. These active metabolites, also known as biogenic compounds, produced by several species of marine macro and microalgae can exert important biological properties such as antibacterial, antifungal, anti-algal and anti micro fouling properties (Kolanjinathan et al. 2014)

According to Ecom et al. (2012), higher antibacterial activity has been recorded in the extracts of brown algae than the red algae extracts and bioactive compounds derived from brown algae have anti-microbial effects and therefore may be useful to explore as potential antimicrobial agents for the food and pharmaceutical industries. Hence, the present study was aimed to formulate low cost feeds incorporate with brown seaweed in order to prevent the susceptibility to some bacterial diseases by immunity enhancing in sea bass culture.

\section{MATERIALS AND METHODS}

This experiment was conducted in an indoor aquarium at the National Aquatic Resource Research and Development Agency, Crow Island, Colombo, Sri Lanka.

\section{Preparation of experimental diet}

Seaweed was collected from shallow coastal areas of Koggala (5 $59^{\prime} 0^{\prime \prime} \mathrm{N}$; 80²0'0” E), in the southern province of Sri Lanka and identified as Sargassum wightii in the laboratory. Collected seaweed sample was cleaned, washed with distilled water and sun dried. Sun dried seaweed was oven dried again at $50^{\circ} \mathrm{C}$ for 15 minutes and grounded into a fine powder.

An isonitrogenous (36\%) and isolipidic (10\%) fish feed was formulated and prepared for conducing the experiment. The formula and proximate analysis of the prepared feed were given in the Tables 1 and 2. All the dried feed ingredients were first powdered and passed through a $0.5 \mathrm{~mm}$ sieve, weighed according to the formula and mixed with vitamin mineral premix, oil and homogenized thoroughly in a mixer and divided into three portions. Then the early prepared seaweed powder was incorporated into two portions of formulated feed mixture with two different rates, $20 \mathrm{~g} / \mathrm{kg}$ and $40 \mathrm{~g} / \mathrm{kg}$ respectively while the rest of the portion was kept without adding see weed powder. Then the three portions of mixture was made into three soft dough by adding water and steam cooked for few minutes. Finally,these three dough were pelletized separately using a hand pelletizer and oven dried at $60^{\circ} \mathrm{C}$ for 12 hours to reduce the moisture content less than $10 \%$.

Table 1 Formula of the experimental feed

\begin{tabular}{ll}
\hline Ingredient & $\%$ Amount $(\mathrm{g})$ \\
\hline Fish meal & 28.0 \\
Shrimp meal & 28.0 \\
Soya bean meal & 28.0 \\
Rice bran & 3.4 \\
Wheat flour & 3.0 \\
Coconut oil & 7.0 \\
Vitamin and mineral mix & 2.6 \\
\hline
\end{tabular}

Table 2 Proximate composition of the experimental feeds

\begin{tabular}{lllll}
\hline & Diet 1 & Diet 2 & Diet 3 & Diet 4 \\
\hline Crude protein & 45.48 & 35.67 & 37.66 & 36.70 \\
Crude fat & 9.56 & 7.50 & 7.78 & 7.67 \\
Moisture & 7.70 & 8.80 & 8.70 & 9.10 \\
Ash & 9.56 & 12.56 & 10.57 & 13.76 \\
\hline
\end{tabular}


Fish rearing and experimental design

Asian sea bass advanced fingerlings were purchased from the private hatchery established in Sri Lanka and were acclimatized to the laboratory conditions for 15 days before the experiment started. During that period they were weaned to the experimental feed from the hatchery fed commercial feed and when the experiment started, were totally fed the experimental feed.

Feed trial was conducted using four treatments (T1 - T4) which comprised a commercial feed (diet 1) fed fish (T1), formulated feed without seaweed(control diet or diet 2) fed fish (T2), formulated feeds incorporated with $20 \mathrm{~g} / \mathrm{kg}$ of $S$. wightii (diet 3) fed fish (T3) and formulated feeds incorporated with $40 \mathrm{~g} / \mathrm{kg}$ of $S$. wightii (diet 4 ) fed fish (T4). All the trials were conducted in triplicates. The imported commercial feed was used in the study to compare the results of the treatments with formulated feed. The experimental trials were conducted in 12 glass aquaria with a size of $60 \mathrm{~cm}$ x $30 \mathrm{~cm}$ x $30 \mathrm{~cm}$. A completely randomized design was used and the effects of these test diets on growth performance were evaluated on fish stocked at the rate of 15 advanced fingerlings $(2.02-2.60 \mathrm{~g})$ per tanks for a period of 40 days.

The proximate composition of the feeds were analyzed according to the official methods of analysis of AOAC methods. Crude protein (CP) was determined by the Kjeldahl procedure (AOAC 1990). Moisture content was quantified by ovendrying $5 \mathrm{~g}$ of feed at $105^{\circ} \mathrm{C}$ until gain a constant weight (AOAC 1990). Total lipid content was determined by soxhlet (AOAC 1995) method.

Feeding was conducted up to their satiation three time a day; $08.00 \mathrm{hrs}, 12.00 \mathrm{hrs}$ and $04.00 \mathrm{hrs}$ during 40 day experiment period. The weight of fish was measured once a week. The continuous aeration was provided throughout the day and $\mathrm{pH}$, temperature, salinity and dissolved oxygen were checked once a week (APHA 1998). One third of water exchange and bottom siphoning was done daily for keeping the water quality clean throughout the experimental period. Mortality and fish behavior were recorded in every feeding time.

The growth parameters, food conversion ratio (FCR), specific growth rate (SGR), weight gain and survival rate were calculated after 40 days using the following formulae.

$$
\text { Weight gain }(\%)=(\text { FBW-IBW/IBW }) \times 100
$$

$$
\begin{aligned}
& \text { Daily Growth Coefficient, DGC }\left(\% \mathrm{~d}^{-1}\right) \\
& =\left\{\left(\mathrm{FBW}^{1 / 3}-\mathrm{IBW}^{1 / 3}\right) / \mathrm{D}\right\} \times 100 \\
& \text { Specific Growth rate,SGR }\left(\mathrm{d}^{-1} \%\right) \\
& \quad=\{[\mathrm{ln} \text { FBW-ln IBW]/D }\} \times 100 \\
& \text { Food Conversion Ratio, FCR } \\
& \quad=\text { (Feed intake/weight gain }) \times 100
\end{aligned}
$$

Food Efficiency Ratio, FER $=1 /$ FCR

Survival rate $(\%) \quad=\left(\mathrm{N}_{2} / \mathrm{N}_{1}\right) \times 100$ where IBW= Initial Body weight $(\mathrm{g})$; FBW= Final body weight $(\mathrm{g})$; and $\mathrm{D}=$ Duration of the experimental period in days. $\mathrm{N}_{1}=$ Number of fish at the start of the experiment; $\mathrm{N}_{2}=$ Number of fish on termination of the experiment.

\section{Procurement of bacteria and challenge test}

Pure cultures of Aeromonas hydrophilawere received from NARA microbiology laboratory. The bacteria culture was stored at $4^{\circ} \mathrm{C}$ until its use in the experiment. The loop-full of bacterial culture was obtained from preserved pure culture to prepare sub-cultures using streak method. The plates were kept in room temperature for 24 hours. Sub-cultures were inoculated into nutrient broth and were incubated for 24 hours in a water bath shaker at $35^{\circ} \mathrm{C}$. The cultures were transferred to sterilized 15 $\mathrm{ml}$ centrifuge tubes and centrifuged at 5,000 rpm for 10 minutes. The supernatant was discarded while the pellet containing bacteria at the bottom of the centrifuge tube was re-suspended in the same volume of sterilized water using a vortex mixer. Similarly, the pellet was washed repeatedly in $5 \mathrm{ml}$ of water for 2 times. Before stating the experiment, $\mathrm{LD}_{50}$ value of bacterial culture was quantified as 1.5 ppm using UV-VIS Spectrophotometer (UV-1700 PharmaSpec) by injecting the bacterial culture into twenty sea bass fishes. This step was done only for getting the general idea of how much sufficient amount has to be injected to the fishes for observing the bacterial disease symptoms.

\section{Comparison of disease prevalence in four different feed types}

After the end of the feed trial, the same fishes in the same order were used for observing the immunity enhancement ability with the introduction of test pathogenic bacteria. Nine fishes per treatment were used for the artificial challenge trial and $1.26 \times 10^{24}$ CFU A. hydrophila for each fish was injected intramuscularly for the experiment. These all challenged fishes were again kept in the same relevant tank and fishes were observed closely for 7 days. Continuous 
aeration was given to minimize the additional stress. Behavioral changes, symptoms and survival rate of the injected fishes were recorded daily and no mortality was observed during the 7 days period. Therefore, the number of infected fishes showing clinical symptoms for each treatment was plotted as disease prevalence against feed type.

Statistical analysis was carried out using Minitab 16 software package. One way ANOVA was used to compare significant differences between treatments at $95 \%$ confidence interval.

\section{RESULTS AND DISCUSSION}

According to proximate composition the highest protein content of $45.5 \%$ was recorded in diet 1 which was the commercial feed. Sakaras et al. (1989) stated that the highest growth rate was achieved with a dietary level of $45 \% \mathrm{CP}$. However, our formulated feed has been prepared to $36 \%$ protein for testing whether there is a possibility to use such a lower protein level for sea bass culture without affecting their growth in the juvenile stages. The protein content of diet 2 (without seaweeds), diet $3(20 \mathrm{~g} / \mathrm{kg}$ of seaweeds) and diet $4(40 \mathrm{~g} / \mathrm{kg}$ of seaweeds) was $35.7 \%, 37.7 \%$ and $36.7 \%$ respectively (Table 2). Iteratively determined protein and amino acid requirements suggest that the requirement for protein and amino acids will decrease with increasing fish size and are largely consistent with empirically determined requirements (Glencross 2006).
The mean weight of sea bass advanced fingerlings belonging to all the treatments has increased during the experimental period of 40 days (Table 3). Significantly higher $(p<0.05)$ weight gain of $4.163 \pm 0.74 \mathrm{~g}$ is recorded from treatment 1 (fish fed with commercial feed) followed by treatment 2 (control treatment) $(2.669 \pm 0.44 \mathrm{~g})$, treatment $4 \quad(2.208 \pm 0.48 \mathrm{~g})$ and treatment 3 $(1.912 \pm 0.18 \mathrm{~g})$ during the 40 days experimental period.

In treatment 2, the weight gain has increased when compared to treatment 3 and 4 . Hence, it conclusively represents that the weight gain is not affected with addition of seaweed. In this experiment, the mean SGR for treatment 1 , treatment 2 , treatment 3 and treatment 4 were not significantly different from each other $(p>0.05)$. Naturally the SGR is increased with increasing the weight gain. Although there were no significant differences at 0.05 probability level, higher SGR (Table 1) was resulted in treatment 1 , which had also higher weight gain. According to the results, we can suggest that there is a possibility to culture sea bass fingerlings with comparatively lower protein level without affecting their growth rates within a shorter period. According to Aquacop et al. (1989) sea bass fingerlings require $45-50 \%$ protein in diets made with high quality fishmeal. The optimal dietary protein level for grow-out sea bass has been reported to range between 40 and $45 \%$ (Wong and Chou 1989).

Table 3 Growth performance and survival rates of Asian sea bass according to the feed type

\begin{tabular}{lllll}
\hline Parameter & $\begin{array}{l}\text { T1 } \\
(\text { Mean } \pm S E)\end{array}$ & $\begin{array}{l}\text { T2 } \\
(\text { Mean } \pm S E)\end{array}$ & $\begin{array}{l}\text { T3 } \\
(\text { Mean } \pm S E)\end{array}$ & $\begin{array}{l}\text { T4 } \\
(\text { Mean } \pm S E)\end{array}$ \\
\hline Initial weight $(g)$ & $2.60 \pm 0.03^{\mathrm{a}}$ & $2.37 \pm 0.08^{\mathrm{a}}$ & $2.26 \pm 0.10^{\mathrm{a}}$ & $2.02 \pm 0.08^{\mathrm{a}}$ \\
Final weight $(\mathrm{g})$ & $6.77 \pm 0.77^{\mathrm{a}}$ & $5.04 \pm 0.45^{\mathrm{ab}}$ & $4.17 \pm 0.25^{\mathrm{b}}$ & $4.23 \pm 0.55^{\mathrm{b}}$ \\
SGR & $2.35 \pm 0.24^{\mathrm{a}}$ & $1.86 \pm 0.21^{\mathrm{a}}$ & $1.52 \pm 0.08^{\mathrm{a}}$ & $1.80 \pm 0.22^{\mathrm{a}}$ \\
FCR & $1.27 \pm 0.10^{\mathrm{a}}$ & $2.17 \pm 0.26^{\mathrm{b}}$ & $2.02 \pm 0.05^{\mathrm{b}}$ & $2.21 \pm 0.50^{\mathrm{b}}$ \\
Survival Rate & $97.78 \pm 2.22^{\mathrm{a}}$ & $86.70 \pm 10.2^{\mathrm{a}}$ & $97.78 \pm 2.22^{\mathrm{a}}$ & $91.11 \pm 5.88^{\mathrm{a}}$ \\
\hline
\end{tabular}

$\mathrm{SE}$ - Standard Error; Values indicated by different superscript in each row are significantly different from each other $(\mathrm{p}<0.05)$

In this experiment, we have observed the growth of the sea bass fingerling for a few weeks and further research for a prolonged period is needed to give a robust recommendation. The growth of fish may differ with their age, size, sex, genetic or metabolic condition, environmental condition, physiological characters and the quality of the feed. Although, we used fishes from the same batch and provided the same conditions to the experiment, one or more such factors can also be influenced to their growth. Regarding SGR, results of the present experiment (Table 3) are in agreement with Hossu 
et al. (2005), who reported that SGR is expected to be around $1.5 \%$ in short periods.

As we used only three replicates for each treatment and as the variability of the samples had been high, there are no significant differences in FCR between the treatments except T1. However, fishes fed with the experimental feeds gave reduced SGR and poor FCR in all treatments, compared to the treatment 1 (i.e., fish fed with commercial feed; Table 3). Better FCR level in fishes fed with the commercial feed must be due to its high protein level.

There was no significant difference $(p>0.05)$ in survival rate of sea bass fed with different feeds (Table 3). The highest survival rate was recorded in treatment $1 \quad(97.78 \pm 2.22)$ and treatment 3 $(97.78 \pm 2.22)$ followed by treatment $4(91.11 \pm 5.88)$ and treatment $2(86.70 \pm 10.2)$. Hence, there was no evidence that sea weed has affected to the survival rate of fish in all types of feeds. Good survival rates of fish were recorded in all the treatments during the study period.

Being a euryhaline species, sea bass can be cultured either in fresh water, brackish water or sea water. The optimum conditions recorded for sea bass farming have been recorded as 10-31 ppt of salinity, 26-32 ${ }^{\circ} \mathrm{C}$ of temperature, $7.5-8.3$ of $\mathrm{pH}$ and
4-8 mg/l of dissolved oxygen (FAO 1988). Salinity, temperature and dissolved oxygen levels in the present study were in the acceptable levels (Table 4). However, a slight deviation of $\mathrm{pH}$ levels could be observed throughout the experimental period. The maintenance of all the water quality parameters at an acceptable level for sea bass culture may have contributed to the reported high survival rate during the feed trial period.

The occurrence of disease was confirmed by the observation of clinical signs when compared to the normal fish (Plates 1 and 2) such as darkening of body color (Plate 3), loss of appetite, red eyes, swollen eyes (Plate 4) or white spots in eyes and behavioral changes such as unbalanced condition, lethargic condition and aggregation into one corner etc. (Plates 5 and 6). The most dominant clinical sign was a darkening of the body color. It was the foremost character for identifying the disease condition of this study. Apart from that gradually they have lost their appetite and all infected fishes showed red, swollen and white spots in eyes (Plate 7). In addition to these clinical signs, behavioral changes in sea bass such as unbalanced condition and aggregation to a corner was observed in fishes infected with $A$. hydrophila.

Table 4 Water quality parameters for different treatments. SE - Standard error

\begin{tabular}{lllll}
\hline Water quality parameter & $\begin{array}{l}\text { T1 } \\
(\text { Mean } \pm \text { SE })\end{array}$ & $\begin{array}{l}\text { T2 } \\
(\text { Mean } \pm \text { SE) }\end{array}$ & $\begin{array}{l}\text { T3 } \\
(\text { Mean } \pm \text { SE })\end{array}$ & $\begin{array}{l}\text { T4 } \\
(\text { Mean } \pm \text { SE) }\end{array}$ \\
\hline Temperature $\left({ }^{\circ} \mathrm{C}\right)$ & $28.48 \pm 0.23$ & $28.20 \pm 0.26$ & $28.42 \pm 0.24$ & $28.5 .55 \pm 0.31$ \\
Dissolved oxygen $(\mathrm{mg} / \mathrm{L})$ & $4.82 \pm 0.28$ & $4.94 \pm 0.18$ & $5.54 \pm 0.16$ & $5.46 \pm 0.12$ \\
pH & $6.78 \pm 0.03$ & $6.74 \pm 0.04$ & $6.68 \pm 0.15$ & $6.68 \pm 0.08$ \\
Salinity $(\mathrm{ppt})$ & $18 \pm 0.54$ & $17.8 \pm 0.37$ & $17.6 \pm 0.4$ & $17.6 \pm 0.08$ \\
\hline
\end{tabular}


Percentage of disease prevalence for $A$. hydrophila of four treatment groups, at the end of the artificial challenge study with A. hydrophila is shown in Figure 1. Disease prevalence used here is given as a percentage of fish that were affected by showing clinical symptoms after the injection of $A$. hydrophila. The lowest disease prevalence was reported from treatment 3 , which was fed with $20 \mathrm{~g} / \mathrm{kg}$ of seaweed incorporated feed. The incorporation of seaweed into the feed may enhance the immunity of sea bass fish. The formulated feed which was incorporated with 40 $\mathrm{g} / \mathrm{kg}$ of seaweeds was also having comparatively low disease prevalence compared to the other two treatments. The highest disease prevalence was reported from T2 (i.e., fishes fed with formulated feed without sea weed). According to the results of present study, it can be suggested that there is a possibility to enhance the immunity of sea bass advanced fingerlings at least up to a shorter period by incorporating $S$. wightii in the diet. However, further research has to be conducted to identify the optimum ratio of this sea weed to be added to the fish feed, for getting the best immunity level.

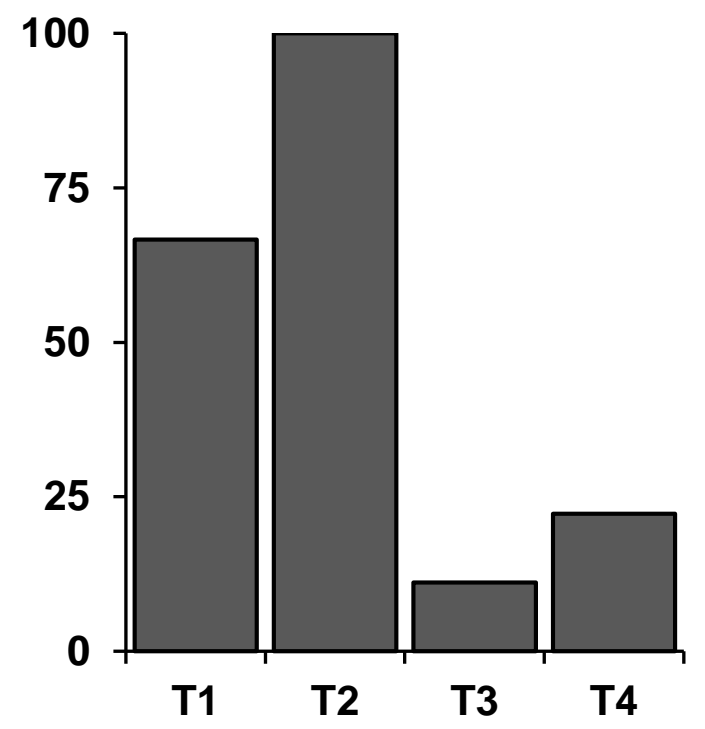

Fig. 1 Comparison of disease prevalence in four different feed types

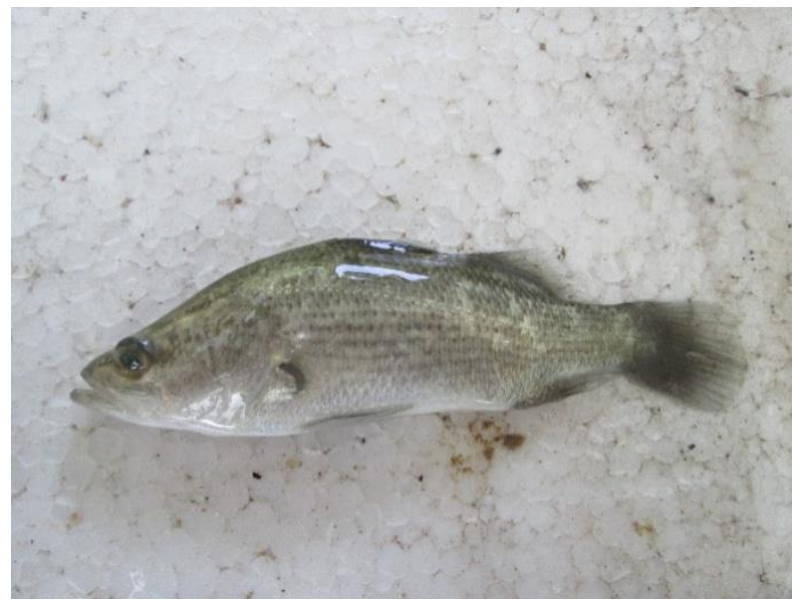

Plate 1 Body colour (normal condition)

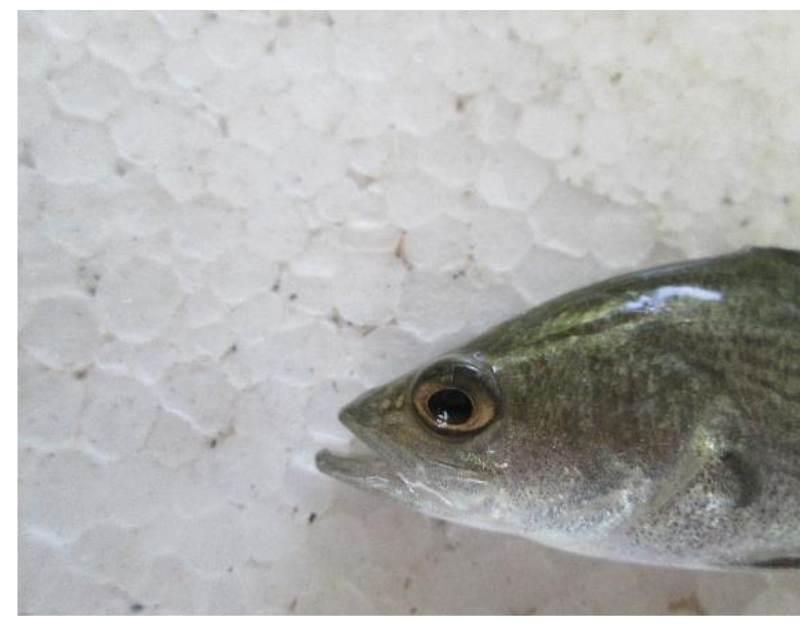

Plate 2 Eyes of the fish (normal condition)

According to Bobadilla et al. (2012), the brown algae has characterized the properties of $\beta$-glucan which is a naturally occurring non-specific immunestimulants. The immuno-stimulants are promising dietary supplement to potentially aid in disease control of several organisms including marine fish and increase disease resistance by regulating host defense mechanisms against opportunistic microorganisms in the environment (Galindo and Hosokawa 2004). S. wightii incorporated feed fed fishes in the present study also confirmed comparatively low disease prevalence, showing high resistance to the challenge test. It may be due to immune-stimulant property of bioactive compounds present in the brown seaweeds. In this study, it can be stated that dietary supplement of immuno-stimulants containing compounds seems to 
be a good choice to induce the disease resistance of the target fish species against $A$. hydrophila pathogens that commonly occur in marine fish culture.
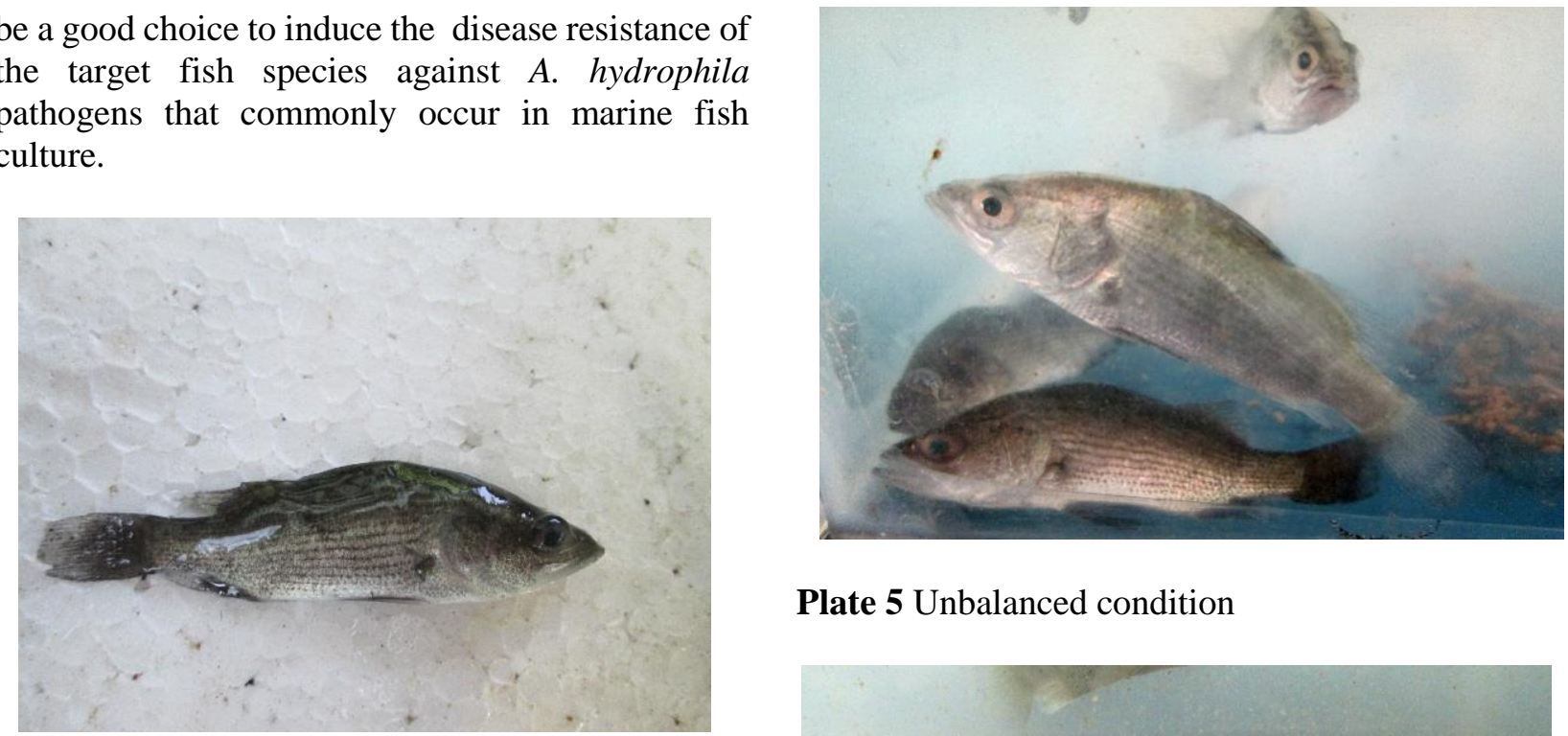

Plate 5 Unbalanced condition

Plate 3 Darkening of body colour (infected condition

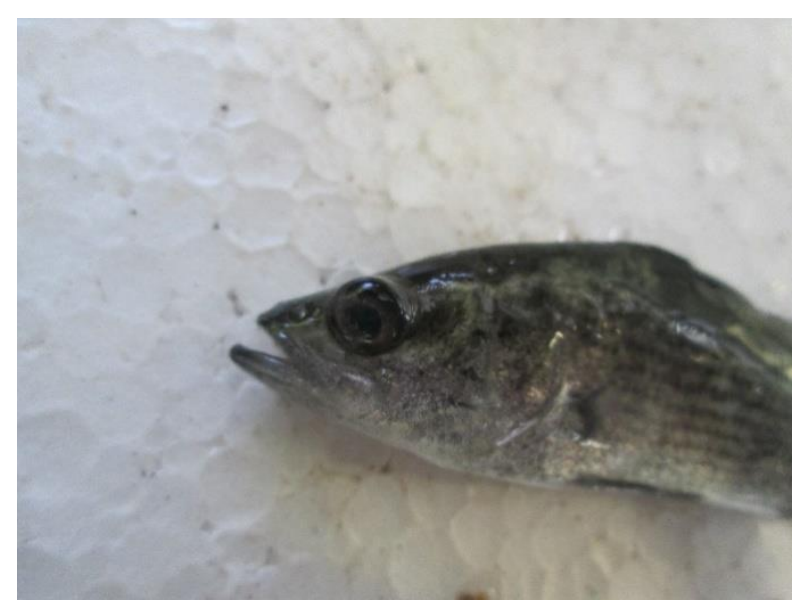

Plate 4 Swollen eye (infected condition

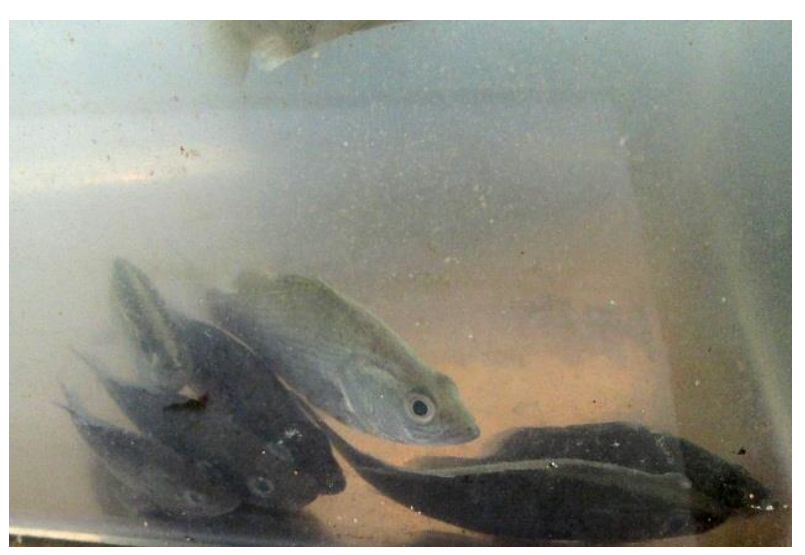

Plate 6 Aggregation of fish into corner

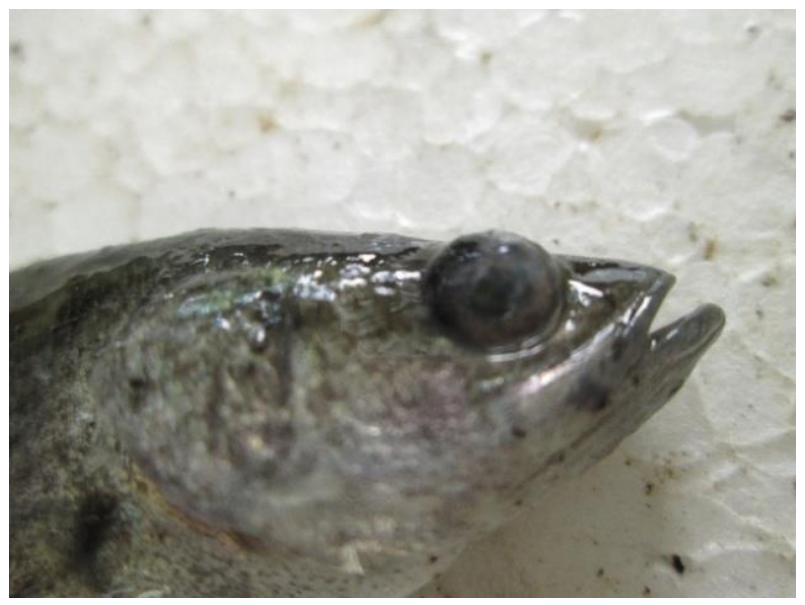

Plate 7 Swollen, red and white spotted eyes 
Approximately Rs. 180.00 of cost was aspired for the formulated feed. In the case of commercial feed it was around Rs. 250.00. Results indicated that the experimental feed showed comparatively lower production cost when compared to the commercial feed which promises the productivity, health and other related benefits. In this study, SGR of the four treatments have not shown a significant difference during the study period. Identification and utilization of locally available ingredients to develop both immunity enhancing and growth increasing low cost feed type for Asian sea bass culture up to the harvest stage will be important to reduce production cost.

\section{CONCLUSION}

The results of the current study revealed the effect of $S$. wightii incorporated feed on immunity development of Asian sea bass. The highest level of immunity enhancement was reported from $20 \mathrm{~g} / \mathrm{kg}$ seaweed-incorporated feed. Since the cost of preparation of sea weed incorporated feed is low, it can be concluded that this experimental feed can be utilized and/or developed as a low cost sea bass feed, which gave a somewhat comparable growth rate compared to the commercial feed.

\section{REFERENCES}

Abou El-Atta M.E. and M.M. El-Tantawy 2008. Bacterial causes of skin ulcers affection in Tilapia nilotica (Orechromis niloticus) with special references to its control. $8^{\text {th }}$ International Symposium on Tilapia in Aquaculture (2008), Central Laboratory for Aquaculture Research, Fish Health Department, Abbassa, Abou Hammad, Sharkia, Egypt.

Anil M.K., B. Santhosh, S.K. Jasmine, N. Saleela, M.G. Ran, K.H. Jose, C. Unnikrishnan, R.G. Hanumanta and R.G. Syda 2010. Growth performance of the sea bass Lates calcarifer (Bloch) in sea cage at Vizhinjam Bay along the south-west coast of India. Indian Journal of Fisheries 57(4): 65-69.

AOAC 1990. Official methods of analysis, 15th Edition. Association of Official Analytical Chemists. Arlington, VA, USA
AOAC 1995. Official methods of analysis, 16th Edition. Association of Official Analytical Chemists. Washington DC, USA.

APHA 1998. Standard methods for the examination of water and wastewater, 20th Edition. American Public Health Association; American Water Works Association; Water Environment Federation. Washington, D.C.

Aquacop, G. Cuxon, R. Chou and J. Fuchs 1989. Nutrition of the sea bass Lates calcarifer. Advances in Tropical Aquaculture, 20 Feb. 4 Mar. 1989, Tahiti, French Polynesia.Aquacop Ifremer. Actes de Colloque 9: 757-763.

Bobadilla F., C. Rodrigues-Tirado, M. Imarai, M.J. Galotto and R. Andersson 2012. Soluble $\beta-1$, $3 / 1,6$ glucan in seaweed from the southern hemisphere and its immune-modulatory effect. Carbohydrate Polymers 92(1): 241-248.

doi:10.1016/j.carbpol.2012.09.071

Boonyaratpalin M. and K. Williams 2002. Asian sea bass, Lates calcarifer. $40-50$ pp. In: C.D. Webster and C. Lim (eds), Nutrient Requirements and Feeding of Finfish for Aquaculture. CAB International Publishing, Wallingford, UK.

Ecom S.H., Y. Mogkim and S. Kim 2012. Antimicrobial effect of phlorotannins from marine brown algae. Food and Chemical Toxicology 50(9): 3251-3255. doi: 10.1016/j.fct.2012.06.028.

FAO 1988. Sea bass (Lates calcarifer) culture in Thailand, (RAS/86/024), Training Manual 88/3. http://www.fao.org/3/contents/fb60fd45-fd1c51af-8b92-5eac47221e8a/AB707E00.htm (accessed August 2017)

Galindo-Villegas J. and H. Hosokawa 2004. Immunostimulants: towards temporary prevention of diseases in marine fish. 279-319 pp. In: L.E. Cruz Suarez, D. Ricque Marie, M.G. Nieto Lopez, D. Villarreal, U. Scholz and M. Gonzalez (eds), Avances en NutricionAcuicola VII. Memoriasdel VII Simposium Internacional de Nutricion Acuicola. 16-19Novembre 20014, Hermosillo, Sonora, Mexico.

Glencross B. 2006.The nutritional management of barramundi, Latescalcarifer- a review. Aquaculture Nutrition 12(4): 291-309. doi: 10.1111/j.1365-2095.2006.00410.x

Hoşsu B., A.Y. Korkut and S. Salnur 2005. Investigation on feeding tables for sea bass 
(Dicentrarchus labrax) in net-cage (Pinar Marine Company) culture. 35-43 pp. In: D. Montero, B. Basurco, I. Nengas, M. Alexis and M. Izquierdo (eds), Mediterranean fish nutrition. Zaragoza: CIHEAM, Cahiers Options Méditerranéennes; n. 63

Kolanjinathan K., P. Ganesh and P. Saranraj2014. Pharmacological importance of seaweeds: A review. World Journal of Fish and Marine Sciences 6(1): 1-15.

doi: 10.5829/idosi.wjfms.2014.06.01.76195
Sakaras W., M. Boonyaratpalin and N. Unprasert 1989. Optimum Dietary Protein Energy Ratio in Seabass Feed II. Technical Paper No. 8, Rayong Brackishwater Fisheries Station, Thailand, 22 pp. (in Thai).

Wong F.J. and F. Chou 1989. Dietary protein requirement of early grow-out sea bass (Lates calcarifer, Bloch) and some observations on the performance of two practical formulated feeds. pp. 91-102. In: Report of the Workshop on Shrimp and Finfish Feed Development. Johor Bahru, Malaysia. 